Ankara Üniversitesi Türk Inkılâp Tarihi Enstitüsü Atatürk Yolu Dergisi S 25-26, Mayı-Kasım 2000 s. 247-250

\title{
Türk İnkılâp Tarihi Enstitüsü Bağışlarınızı Bekliyor
}

\author{
Mustafa TOKER*
}

Türk İnkılâp Tarihi Enstitüsü, ilk olarak Dil, Tarih-Coğrafya Fakültesinde kurulması düşünülmüştür. Buna dair kanun layihası, 14 Ocak 1942'de meclise sunulmuştur. Bu layihada kurulacak olan enstitünün vazifeleri şu şekilde belirtilmişti.

Türk İstiklal Savaşı'nın, Türk İnkılâbı ve Türkiye Cumhuriyeti rejiminin dayandığı esaslar hakkında her türlü araştırma ve incelemeler yapmak, bu mevzularla ilgili belgeleri ve yayınları toplayarak kütüphane ve müzeler meydana getirmek ve bir arşiv kurmak, Türk İnkılâbı'nı ve rejimini memleket içinde ve dışında tanıtmak için dersler ve konferanslar vermektir ${ }^{1}$.

9 Nisan 1942 'de meclise sunulan bu layiha doğrultusunda Türk İnkılâp Tarihi Enstitüsü projesi ilk kez müzakere edildi. Müzakere başladıktan sonra, Dil, Tarih-Coğrafya Fakültesine bağlı "Türk İnkılâp Tarihi Enstitüsü" kurulması hakkındaki kanun layihasının üçüncü maddesine dair Maarif Encümeni mazbatası okundu.

Görüşmelerde söz alan İstanbul Mebusu Kazım Karabekir, üçüncü maddeye ait mazbatadaki "İnkılâp" kelimelerinden önce "İstiklal ve" kelimelerinin eklenmesi ve enstitüde bulundurulacak olan şeref defterine yazılacak bağışlamaların, yalnız resmi gazetede değil radyo ile neşrini teklif etti. Takrir okunarak kabul olundu ${ }^{2}$.

16 Nisan 1942'de enstitü hakkında ikinci görüşme yapıldı. Kazım Karabekir'in "Türk İnkılâp Tarihi Enstitüsü" yerine "Türk İstiklal ve İnkalâp Tarihi Enstitüsü" denilmesi hakkındaki takriri yeniden okunmasından sonra, Başbakan Refik Saydam kürsüye gelerek, "Arkadaşlar, biz bu enstitünün kanununu gönderirken, bundan önce de inkılâp dersleri vardı. Onun yerine bu enstitüyü kurduk. İsminin

\footnotetext{
• Ankara Üniversitesi Türk İnkilâp Tarihi Enstitüsü uzmanı.

${ }^{1}$ Cumhuriyet, 14 Ocak 1942, s. 1.

${ }^{2}$ Ulus, 9 Nisan 1942, s. 1.
} 
değiştirilmesine şahsen bir lüzum göremiyorum. Zaten teklif kanununun ruhundadır. Binaenaleyh, inkılâp enstitüsü şeklinde kalması arkadaşlarımız tarafindan da tercih ediliyor. O kalırsa daha muvafik olur." ${ }^{3}$ şeklinde bir konuşma yaparak enstitünün adının değiştirilmemesi gerektiğini belirtti.

Bu konuşmayı müteakip, Kazım Karabekir'in "Türk Inkılâp Tarihi Enstitüsü" yerine "Türk İstiklal ve İnkllâp Tarihi Enstitüsü" denilmesine dair ikinci takriri okundu ve oylamaya konan her iki takrir dikkate alınmayarak kanun layihası ayrıca Büyük Millet Meclisinde kabul edildi ${ }^{4}$.

Böylece Türk İnkılâp Tarihi Enstitüsü, 4204 sayılı kanunla Dil, TarihCoğrafya Fakültesine bağlı olarak kurulmuş oldu. Daha sonra 2547 sayılı Yüksek Öğrenim Kanunu ile yüksek lisans ve doktora programları uygulayan bir bilim haline dönüştürülerek Ankara Üniversitesi Rektörlüğüne bağlandi.

Türk İnkılâp Tarihi Enstitüsünün amaçları, genel olarak yönetmeliğinde şu şekilde belirtilmiştir; Türk İstiklal Savaşı, Türk İnkılâbı ve Türkiye Cumhuriyeti rejiminin dayandığı esaslar hakkında araştırmalar yapmak, bu konularla ilgili belge, yayın ve eşyaları toplayarak kütüphane ve müzeler meydana getirmek, arşiv kurmak, Türk İnkılâbını memleket içinde ve dışında tanıtmak için konferanslar vermek ve her türlü yayımlar yapmak ${ }^{5}$.

Yukarıdaki amaçlar doğrultusunda çalışmalar başlatılarak, Türk İstiklal Savaşı, Türk İnkılâbı ve Türkiye Cumhuriyeti rejimine ait; kitap, arşiv belgeleri, eşyalar toplanmaya başlanmıştır. Bu tür malzeme toplanırken 14 Ocak 1942'de kabul edilen layihadaki bir hükümde, "Bütün resmi ve milli makam ve kurumlar, kendi dosya ve arşivlerinde bulunan inkılâp tarihi ile alakalı her nevi evrak ve belgelerin asıl veya suretlerini Maarif Vekilliği tarafindan lüzum gösterildikçe, bu enstitüye vereceklerdir." ${ }^{\prime}$ Hükmü de dikkate alınmakta idi.

Türk İnkılâp Tarihi Enstitüsünün için gerekli malzemeyi toplamak amacıyla gazetelere ilanlar da verilmişti. "Türk İnkılâp Tarihi Enstitüsü İstiklal Savaşına Ait Bütün Eserleri Topluyor” başlıklı bir gazete ilanında:

"Yeni teşekkül eden Türk Inkılâp Tarihi Enstitüsü Müdürlü̆gü bütün vilayetlere bir tamim yaparak, istiklal savaşına ve inkılap tarihimizle alakalı her türlü vesika ve eşyaların toplanmasını istemiştir. Bu tamim üzerine valiler, müdürlüklere gereken emirleri vermişlerdir.

Evvela müdürlükler, Belediye müesseseleri, milli kurumlar kendi dosya ve arşivlerinde her türlü milli inkılâp tarihimizde alakalı eserlerin asıllarını,

\footnotetext{
${ }^{3}$ Ulus, 16 Nisan 1942, s. 1.

${ }^{4}$ Ulus, 16 Nisan 1942, s. 1-5.

${ }^{5}$ T.C. Maarif Vekilliği, Türk İnkılâp Tarihi Enstitüsü Yönetmeliği, Ankara 1943, s. 10.

${ }^{6}$ Cumhuriyet, 14 Ocak 1942, s. 1.
} 
suretlerini enstitüye göndereceklerdir. Ayrıca bağışta bulunanların adlart enstitünün şeref defterine kaydedilecek resmi gazete ile de ilan edilecek, kendilerine "Şeref Diploması" adıyla enstitü tarafından bir diploma verilecektir. Ayrıca bu eşyaları bu şekilde vermeyen satmak isteyenlerden de enstitü eşyalart takdir edecek kıymetle satın alacaktır. Enstitünün istediği eserler şunlardır:

Milli savaşa ait türlü eşya, önemli vesikalar, kıyafet inkılabı, bundan önceki kadın ve erkek klyafetleri, yazı, dil inkılabı, inkılap tarihine ait istatistikler, grafikler, sulu boya tablolar, resimler, inkılap adamlarına ait resimler, eserler ve vesikalardır."7 denilerek, Türk İnkilap Tarihi Enstitüsü için gerekli materyaller belirtilmiştir.

Diğer taraftan, İstiklal Savaşı'na katılan, bu savaşta bizzat görev alan şahıslara da yazılar yazılarak ellerindeki materyalleri enstitüye vermeleri istenilmişti. Esat İleri, Türk İnkılâp Tarihi Enstitüsü müdürüne yazdığı bir mektupta; elindeki vesikaları hiç bir gazeteciye vermediğini belirterek, enstitü müdür yardımcısının, İzmir'de çıkan Anadolu Gazetesi'ndeki beyanını okuduktan sonra İzmir'e gelmişti. Burada enstitü müdür yardımcısı ile görüşerek belgeleri teslim etmiş belgelerin bir suretinin de kendisine gönderilmesini istemişti ${ }^{8}$.

Yine Dr. A. Rıza Oktay, 1945 yılında enstitüye gönderdiği, İzmir'in İşgali üzerine İstanbul'da yapılan mitingler, Gediz ve Anadolu'da milli harekat hatıralarından oluşan vesikaların, İlmi Danışma ve Yönetim Kurulunca kabul edildiğini, bu vesikaların suretlerinin kendisine gönderilmesini istemişti ${ }^{9}$.

Gerek gazetelere verilen ilanlar gerekse bir döneme tanıklık etmiş kişilerin ellerinde bulunan malzemeler; arşiv belgeleri, kitap ve eşyalar enstitü için toplanmaya başlanmıştı. Ancak her gönderilen yazıdan olumlu sonuçlar çıkmayabiliyordu. Nitekim, Adil Sayar'dan İstikal Savaşı'nda Balıkesir harekat ve mücadelesi ile ilgili vesikalar istenilmiş, Adil Sayar, Türk İnkılâp Tarihi Enstitüsü Müdürlügüne gönderdiği cevabi mektupta; Balıkesir'deki evrakların, işgal üzerine Eskişehir'e gönderildiğini, fakat Eskişehir'in de işgali üzerine taşınamayacak bir halde bulunan evrak sandığının Eskişehir'de Zeytinzadelerin ahşap mağazalarının bodrumuna konulduğunu, kurtuluşu müteakip geri dönüldüğünde mağazanın bir kül haline gelmesi nedeniyle kendisinde hiç bir evrakın olmadığını belirtmişti. Adil Sayar mektubuna:

"Türk İnkılâbı gibi milli tarihimizi şereflendirecek çok de ğerli eserinize benim de bir kaç satır ilave edememiş olmadığından dolayı pek müteesirim. Böyle bir vesikaya malik olsaydım bunu-kıymetli ne olursa olsun-satmak

${ }^{7}$ TiTE. Arşivi; Kutu No: 93, Gömlek No: 30, Belge No: 30-46.

${ }^{8}$ TITE. Arșivi; Kutu No: 71, Gömlek No: 27, Belge No: 27, 14 Kasım 1944.

${ }^{9}$ TiTE. Arşivi; Kutu No: 72, Gömlek No: 7, Belge No: 7-11, 6 Haziran 1949. 
suretiyle değil bila-bedel ve kemal-l iftiharda takdim edeceğime itimat buyurmanızı rica eder, derin sayglarımı sunarım."10 sözleriyle son veriyordu.

Bugün enstitümüz bünyesinde bulunan kitap, arşiv belgeleri, müze malzemesi işte bu süreçlerden geçerek büyük uğraşlar sonucu elde edilmiştir. Enstitümüz bağışta bulunan kurum, kuruuş ve şahıslar, Türk İnkılâp Tarihi Enstitüsü Arşiv ve Kütüphanesindeki şeref panosunda isimleri yazılmak suretiyle kendilerine olan minet borcu bir şekilde gösterilmeye çalışılmıştır. Bu şahıslardan bazıları; Refet Bele, Bekir Sıtkı Baykal, Hacim Muhittin Çarıklı, Kazım Karabekir, Hüsrev Gerede, Avni Gelendost, Rahmi Apak, Fahri Belen, Enver Behnan Şapolyo, Gıyas Yetkin'dir.

Bu konuda, Eski Nafia Vekili, Budapeşte ve Paris Büyükelçisi Behiç Erkin'in katkıları büyük olmuştur. Behiç Erkin, enstitümüze önemli miktarda arşiv belgesi, kitap, müzelik eşya bağışlamıştır.

Kurum ve kuruluşlardan bazıları ise; Afyon Valiliği, Bitlis Valiliği, Bergama Halkevi, Konya Valiliği, Kırşehir Valiliği, İzmir Valiliği, Urfa Valiliği, Muğla Valiliği, Eskişehir Valiliği, Erzurum Valiliği, Dışişleri Bakanlığı, Polis Enstitüsü'dür.

Ayrıca elinde bu tür malzeme bulunan kişiler bunları bağış olarak değil malzemeyi satmak suretiyle enstitüye katkıda bulunmuşlardır.

Halen enstitmüz kütüphanesinde 9.000 dolayında kitap bulunmaktadır. Arşiv kısmı ise; 1995 yılında faaliyete geçmiştir. Arşivde mevcut belgelerin, bilgisayara uyarlı analitik tasnif işlemlerine başlanmış ve bugüne kadar TİTE-A1, TİTE-A2, TİTE-A3, TİTE-A4, TİTE-A5, TİTEA6, TİTE-A7, TİTE-A8 Katalogları hazırlanmıștır. Tasnif çalışmaları devam etmektedir. Müze kısmı haftanın çalışma günleri ziyaretçilere açıktır.

1942 yılındaki ilanı burada tekrar yinelemek istiyoruz. Elinde, Türk İstiklal Savaşı, Türk İnkılâbı ve Türkiye Cumhuriyeti rejimine ait her türlü eser, arşiv belgesi, fotoğraf, film, müzelik eşyaya sahip olanların, bu materyaleri enstitümüze bağışlamalarını bekliyoruz.

Bunun için aşağıdaki adresten irtibata geçebilirsiniz.

Adres:

A.Ü. Türk İmkılâp Tarihi Enstitüsü Müdürlüğü Ziraat Fakültesi Gıda Mühendisliği 4 Nolu Bina Zemin Katı, Keçiören Yolu 06280 / ANKARA

Telefon: (0312) 3604013 - 3609790

Faks: (0312) 3594308

E-Posta: tite@humanity.ankara.edu.tr

${ }^{10}$ TiTE. Arşivi; Kutu No: 72, Gömlek No: 2, Belge No: 2. 2-1, 2-2. 


\section{“ATATÜRK YOLU” DERGISINDDE YAYINLANACAK MAKALELER İÇIN BILLGI NOTU}

\section{Genel Kurallar}

1. Atatürk Yolu dergisi Mayıs 2002 tarihinden itibaren "Hakemli Dergi" statüsünde ve yılda iki kez (Mayıs-Kasım aylarında) yayımlanacaktır.

2. Dergiye gönderilen yazılar daha önce başka yerde yayımlanmamış veya yayımlanmak üzere aynı anda başka bir yere gönderilmemiş olmalıdır. Yazılar kabul edildiği andan itibaren "Atatürk Yolu" dergisi tüm yayın haklarına sahiptir.

3. Dergiye gönderilen yazılar, Danışma Kurulu tarafından ilk değerlendirilmesi yapıldıktan sonra hakemlere gönderilecek ve hakemden gelecek rapor doğrultusunda yazının basılmasına, hakem raporu doğrultusunda düzeltme istenmesine veya geri çevrilmesine karar verilecektir. Durum en kısa sürede yazarına bildirilecektir.

4. Derginin bir sayısına fazla yazı gelmesi durumunda yazarın da onayı alınarak yazı bir sonraki sayıda yayımlanabilecektir.

5. Yazarlar, unvanlarını, görev yaptıkları kurumları, haberleşme adresleri, telefon belgegeçer numaralarını bildireceklerdir.

6. Dergiye gönderilen yazılar (disketi ile birlikte) teslim alındıkdan sonra düzeltme için yazara geri gönderilmeyecektir. Çok fazla yazım yanlışı bulunan yazılar geri çevrilecektir.

7. Yazısı kabul edilen yazara derginin yayımlanmasından sonra telif ücreti ödenecektir.

8. Dergide yayımlanan yazıdan 20 adet tıpkıbasım ve 5 adet dergi yazara ücretsiz olarak gönderilecektir.

\section{ATATÜRK YOLU" Dergisi Yazı Formatı}

1. Türkçe makale başlığının altına özetin yazıldığı yabancı dildeki karşılığı, makale yabancı dilde yazılmış ise Türkçe karşılığı yazılacak,

2. Makale adı ve yazar adından sonra 200'er kelimeyi geçmeyecek şekilde Türkçe özet "ÖZ” ve yabancı dilde özet "ABSTRACT" yazılacak,

3. Makale yazımında; (yazı tipi Times New Roman) 
a) Başlık 14 punto koyu, yabancı karşılığı 13 punto normal ve her iki dilde de kelimelerin ilk harfleri büyük; yazar ad1 12 punto koyu; Öz ve Abstract 10 punto italik; metin 11 punto normal, dipnotlar 9 punto, kaynakca 10 punto yazılacak,

b) Metinde satır aralığı 1 (tek), paragraf başı boşlukları 0.5 , dipnot başlangıçları 0.5 olacak,

c) Makale içindeki ana başlıklar metnin yazıldığı puntoda, boşluk bırakılmadan, koyu ve küçük harflerle yazılacak, alt başlıklar hiyerarşik bir yapı izlenerek oluşturulacak ve tek biçimlilik sağlanacak,

d) Dipnotlar aynı sayfa altında verilecek,

e) Dipnotlarda ve/veya kaynakçada yayın adları (kitaplarda kitap adı, makalelerde dergi adı) italik yazılacak, atıflarda alıntı yapılan sayfa numarası mutlaka belirtilecek,

f) Atıfta bulunulan kaynağın tam kimliği verilecek, atıfta bulunulmamış eserler verilerek kaynakca şişirilmeyecek,

g) Kaynakçada yazar adları küçük harflerle yazılacak,

h) Sayfa numarası altbilgi/üstbilgi kısmından verilecek,

i) Üstbilgi alanından çift numaralı sayfalara yazar adı, tek numaralı sayfalara makale adi 9 punto yazılacak

j) Her makalenin başlangıcında, makalenin kimlik bilgisi verilecek, (Örn. Ankara Üniversitesi Türk İnkılâp Tarihi Enstitüsü Atatürk Yolu Dergisi, S. 22, Kasım 1998, s. 1-10).

4. Ekler yazının sonunda verilecek ve altında belgenin içeriği hakkında kısa bir bilgi ile bilimsel kaynak gösterme ölçütlerine uygun bir şekilde kaynak yer alacaktır.

Haberlesme Adresi: Ankara Üniversitesi Türk İnkalâp Tarihi Enstitüsü

Guda Mühendisliği 4 nolu bina zemin kat No. $2 / 4$ 06280 Keçiören / ANKARA

Tel: (0312) $3604013 \quad$ Belgegeçer: (0312) 3594308 